\title{
Impact of Different Spacings of Cooking Banana Intercropped with Rubber on Soil Fertility Attributes and Maturity Rate of the Trees in a Humid Forest Area of South Eastern Nigeria
}

\author{
Timothy U. Esekhade, Ikokwu K. Okore* \\ Rubber Research Institute of Nigeria, Benin City, Nigeria \\ Email: "iko7796@yahoo.co.uk \\ Received December $28^{\text {th }}, 2011$; revised February $29^{\text {th }}, 2012$; accepted March $7^{\text {th }}, 2012$
}

\begin{abstract}
The impact of four spacing of cooking banana (CB) within the immature rubber avenues on some soil fertility attributes, maturity rate of rubber trees and dry rubber content (DRC) during the initial six years after planting (YAP) were evaluated in a humid forest area of South Eastern Nigeria relative to sole rubber. The CB spacings within immature rubber avenues were $6.7 \times 3.4 \mathrm{~m} ; 4.0 \times 2.0 \mathrm{~m}, 3.0 \times 3.0 \mathrm{~m}$ and $2.0 \times$ $2.0 \mathrm{~m}$, while the sole rubber was at $6.7 \times 3.4 \mathrm{~m}$, all laid out in randomized complete block design with five replications. Quantities of soil organic C, extractable $\mathrm{P}, \mathrm{Ca}, \mathrm{Mg}$ and earthworm activities were significantly higher in the intercrops, with the highest value coming from the $4 \times 2 \mathrm{~m} \mathrm{CB}$ spaced plots. However a significantly higher value of $\mathrm{K}$ stock was observed in the sole rubber plot and declined as the $\mathrm{CB}$ spacing narrowed. While the highest proportion (>90\%) of matured hevea tree at six YAP was observed in the $2 \times 2 \mathrm{~m} \mathrm{CB}$ spaced plots; the highest DRC of $1.7 \mathrm{t} \cdot \mathrm{ha}^{-1} \cdot \mathrm{yr}^{-1}$ was obtained from $\mathrm{CB} 4 \times 2 \mathrm{~m}$ treatment. Consequently, with some of the observed soil fertility attributes and DRC recorded, $4 \times 2 \mathrm{~m}$ CB spacing seems to be a more suitable $\mathrm{CB}$ spacings within immature rubber avenues, especially in view of the levels of $\mathrm{K}$ in the $2 \times 2 \mathrm{CB}$ plots.
\end{abstract}

Keywords: Cropping System; Nutrient Stock; Dry Rubber Content; Earth Warm

\section{Introduction}

Majority of the world natural rubber (Hevea brasiliensis Muel. Arg) is traditionally and economically grown in the low land humid tropics. This is principally due to its requirement for uniform rainfall distribution, reduced temperature fluctuation and relative humidity all year round (Von Uexckull \& Mutert, 1995; Rao et al., 1998). Soils of the eco-region are known to be predominantly of low activity clay minerals characterized by poor mineral nutrient fixation and/or storage capacity (Fagbani \& Fapohund, 1986). Although this inherent fertility constraint posses a lot of management problem upon the conversion of the native forest into agriculture use (Von Uexckull \& Mutert, 1995); the soils are known for their sustenance of the natural luxuriant tropical rainforest vegetation (Novrdwijik, 2002). A number of low external input cropping systems are traditionally used in the management of the soils when put to agricultural use. Such management method includes diversification of crop component of the system through inter cropping.

Intercropping of rubber with arable and quasi-peremial crops like banana and pineapples has been found to be a sure way of ameliorating the problem of zero income phase (immaturity phase which often spans between 5 - 6 years) in rubber cultivation (Esekhade \& Ojiekpon, 1997; Rodrigo et al., 2004) especially amongst the small holding who constitute over $75 \%$ of rubber growers (IRSG, 2000). Reports on the effect of various inter crop components on soil nutrient status (Zainol et al.,

${ }^{*}$ Corresponding author.
1993; Esekhade et al., 2005) income enhancement; (Lydia et al., 1999) and resource use efficiency (Rodrigo et al., 1997) and growth performance of rubber sapling (Rodrigo et al., 2004) are often limited to the immature period of the main crop (rubber). There is paucity of information on the effect of the intercrop components on the subsequent growth and yield and the soil fertility attributes at the maturity of the main crop.

Consequently, it is the objective of this study to evaluate the effect of different spacing of a Musa spp in an inter crop with rubber on some soil fertility indicators such as nutrient stock and earthworm activities at the maturity and maturity rate (attainment of tappable girth size) of the main crop under such cropping system in high rainforest area of south eastern Nigeria.

\section{Materials and Methods}

\section{Site Description}

The study herein reported is the extension of an experiment established in 1993 (Esekhade \& Ojiekpon, 1997) on the intercropping of Para rubber (Hevea brasiliensis Mull. Arg) and Musa Spp (cooking banana) in an acid sand soil of Akwete, South eastern Nigeria. Akwete lies at Lat. $4.8998^{\circ} \mathrm{N}$ and Long. $7.3359^{\circ} \mathrm{E}$. The rainfall pattern is bimodal with peaks in the months of June, July and September and a mean minimum and maximum temperature of $23.7^{\circ} \mathrm{C}$ and $32^{\circ} \mathrm{C}$, respectively.

The landscape is nearly plain with a maximum elevation of $2 \%$ and the soil being classified as Arenic plaudit (USDA) or Dystric Nitroso (FAO) and sandy alluvium parent material 
(Fabgbami \& Fapohunda, 1986). At 0 to $30 \mathrm{~cm}$ depth the soil had $84 \%$ sand, $8 \%$ silt and $8 \%$ silt with CEC of 6.40 $\mathrm{Cmol} \cdot \mathrm{Kg}^{-1}$, Organic matter of $1.8 \%$ and a $\mathrm{pH}$ of 4.4 .

\section{Experimental Layout}

The experiment was laid out in Randomized Complete Block Design (RCBD). The treatment consist of sole rubber at the spacing of $6.7 \times 3.4 \mathrm{~m}$ and four intercrop spacing $(6.7 \times 3.4 \mathrm{~m}$, $4.0 \times 2.0 \mathrm{~m}, 3.0 \times 3.0 \mathrm{~m}$ and $2.0 \times 2.0 \mathrm{~m}$ ) of cooking Banana within immature rubber avenue of $6.7 \times 3.4 \mathrm{~m}$. Each of this treatment was replicated five times. The rubber clones and cooking banana cultivar used are RRIM 501 and Cadaba, respectively. Details of the field arrangement and management practices are contained in Esekhade and Ojiekpon (1997).

\section{Maturity Rate Determination}

The effect of Banana spacing on maturity period (rate) of rubber trees was assessed by measuring the girth of 15 trees at the height of $1.5 \mathrm{~m}$ above the bud grafted union at six months intervals in each treatment from the third year after planting. However, for ease of handling, data are presented on yearly basis.

\section{Dry Rubber Yield (DRC) Determination}

For DRC determination, latex exploitation of the trees between 1999 and 2001 was used. The $\mathrm{S}_{2} \mathrm{D}_{2}$ (half-Spiral, every third day) tapping method was deployed to obtain the latex. The dry rubber content (DRC) of the latex was determined by air drying at room temperature until a constant weight was obtained.

\section{Soil Analysis Procedure and Nutrient Stock Determination}

Composite soil samples were taken at the depths of $0-15$ and $15-30 \mathrm{~cm}$ at the onset of the experiment. At the beginning of latex exploitation, composite samples were equally taken across the treatments at similar depth like those of the pretreatment samples. The composite samples consisted of four random sub samples from each treatment. All the samples were air dried and sieved through a $2 \mathrm{~mm}$ mesh sieve. The sample were analyzed for organic $\mathrm{C}$, total $\mathrm{N}$, available $\mathrm{P}$ and exchangeable bases $\left(\mathrm{Ca}^{2+}, \mathrm{Mg}^{2+}\right.$ and $\left.\mathrm{k}^{+}\right)$following Page et al. (1982) procedure. Stored nutrients (extractable $\mathrm{P}, \mathrm{K}, \mathrm{Ca}$ and $\mathrm{Mg}$ and total $\mathrm{N}$ and organic C) in each of the treatment were calculated by multiplying the soil concentration by the bulk-destiny and thickness of the soil horizon considering the soil mass of each of the treatment (Ellert \& Bettary, 1995).

\section{Earthworm Activities Determination}

For earth worm activities determination, surface casts were sampled from five randomly placed $1 \times 1 \mathrm{~m}$ wooden quadrant in each experimental unit at the end of rains at the third and sixth year after planting. The cast were dried at $105^{\circ} \mathrm{C}$ for weight determination. From similar quadrants soil monoliths $(50 \times 50 \times 20 \mathrm{~cm})$ were obtained using the Tropical soil Biology and Fertility (TSBF) approach (Anderson and Ingram, 1993). Earth worm in each monolith were hand sorted and put into $10 \%$ ethanol and later transferred to $40 \%$ formaldehyde before being counted and weight for abundance and biomass evaluation respectively.

Data generated were subjected to analysis of variance using RCBD procedure. Where significance differences occurred for a given variable across the treatment means were separated by the use of Least Significant Difference (LSD) approach.

\section{Results}

\section{Soil Nutrient Stock}

As shown in Table 1, the effect of the inter crops (irrespective of the spacing of the cooking banana) on the stocks of nutrients measured except $\mathrm{N}$ and $\mathrm{K}$, were significant (higher) compared to the sole rubber at $0-15$ and $15-30 \mathrm{~cm}$ soil depths. Organic $\mathrm{C}$ accumulation across the treatments followed similar trend. The stock of organic C (30.87 and $\left.28.36 \mathrm{Mg} \cdot \mathrm{ha}^{-1}\right)$ obtained at the inception of tapping from plots where cooking banana were intercropped at the spacing of $6.7 \times 3.4$ and $4 \times 2$ $\mathrm{m}$, respectively within the rubber avenue, differed significantly from the $24.53 \mathrm{Mg} \cdot \mathrm{ha}^{-1}$ obtained from the sole rubber at $0-15$ $\mathrm{cm}$. The result at the lower depth $15-30 \mathrm{~cm}$ followed the same trend. The effect of the cooking banana spacing within the rubber avenues on total $\mathrm{N}$ stock did not differ significantly from that of the sole plot at $0-15 \mathrm{~cm}$, but did at the $15-30 \mathrm{~cm}$ depth. The highest value $\left(112 \mathrm{kgN} \cdot \mathrm{ha}^{-1}\right)$ at $15-30 \mathrm{~cm}$ depth was recorded from plots with $4 \times 2 \mathrm{~m}$ spacing of cooking banana. The stock of available $\mathrm{P}$ and exchangeable bases $(\mathrm{Ca}$ and $\mathrm{Mg}$ ) differed significantly between the intercrop plots and the sole with higher values being recorded from the intercrops with exception of $\mathrm{K}$. The effect of the component crop spacing within the rubber avenue showed that as the spacing narrowed, the soil $\mathrm{P}$ stock decreased with a significantly higher values being obtained from $6.7 \times 3.4$ and $4 \times 2$ m compared to $3 \times 3$ and $2 \times 2$ $\mathrm{m}$ cooking banana spaced plots at the two depths.However, the values from the intercrop were significantly higher than those recorded from the sole plots. The stocks of exchangeable $\mathrm{Ca}$ and $\mathrm{Mg}$ across the treatments followed similar trend, while the stock of $\mathrm{K}^{+}$in the soil under sole rubber was significantly higher than those of the inter crops with values amongst the intercrops following the $\mathrm{P}$ distribution tend (Table 1) irrespective of the soil depth.

\section{Earth Worm Activities}

Earth worm activities measured as surface cast, biomass and abundance (Table 2) differed significantly across the treatments irrespective of the sampling period (three or six YAP).

The quantities of the surface cast deposited across the inter crops at any of the sampling period, were significantly higher than those of the sole cropping irrespective of the component crop spacing within the rubber avenue. Amongst the intercrops, as the spacing of the $\mathrm{CB}$ within the main crop narrowed, the quantity of earth worm cast deposit increased at the third year after planting. However, this differed at the sixth year after planting with highest cast deposit $\left(442.06 \mathrm{~g} \cdot \mathrm{m}^{-2}\right)$ being obtained from plots with $\mathrm{CB}$ spaced at $4 \times 2 \mathrm{~m}$ within the rubber avenue. The effect on earth worm biomass and abundance followed similar trend with the intercrop system having higher values.

\section{Rubber Tree Maturity Rate}

On rates of the attainment of tappable girth size amongst rubber 
Table 1.

Effect of cooking banana spacing in an intercrop with rubber on the quantities of nutrient $\left(\mathrm{kg} \cdot \mathrm{ha}^{-1}\right)$ and organic $\mathrm{C}\left(\mathrm{Mg} \cdot \mathrm{ha}^{-1}\right)$ stored in the soil $(0-30 \mathrm{~cm})$ at 6 years after planting (maturity period).

\begin{tabular}{cccccccc}
\hline \multirow{2}{*}{$\begin{array}{c}\text { Treatment } \\
\text { (Cooking banana Spacing) }\end{array}$} & Org. & Total & Avail. & \multicolumn{3}{c}{ Exchangeable } \\
\cline { 2 - 7 } & $\mathbf{C}$ & $\mathbf{N}$ & $\mathbf{P}$ & $\mathbf{C a}$ & Mg & K \\
\hline Rubber sole $6.7 \times 3.4 \mathrm{~m}$ & 24.53 & 125.52 & 24.62 & 109.1 & 107.3 & 83.01 \\
Rubber + CB $(6.7 \times 3.4 \mathrm{~m})$ & 28.36 & 128.3 & 44.66 & 121.22 & 113.41 & 63.42 \\
Rubber + CB $(4.0 \times 2.0 \mathrm{~m})$ & 30.87 & 128.13 & 43.68 & 121.1 & 113.21 & 65.66 \\
Rubber + CB $(3.0 \times 3.0 \mathrm{~m})$ & 26.88 & 128.1 & 36.95 & 119.32 & 117.72 & 61.62 \\
Rubber + CB $(2.0 \times 2.0 \mathrm{~m})$ & 26.88 & 126.3 & 34.12 & 134.12 & 118.1 & 55.32 \\
LSD $(0.05)$ & 3.36 & NS & 6.35 & 10.15 & 4.62 & 15.32 \\
\hline Rubber sole $6.7 \times 3.4 \mathrm{~m}$ & 16.42 & 98.21 & 30.34 & 30.24 & 25.72 & 19.09 \\
Rubber + CB $(6.7 \times 3.4 \mathrm{~m})$ & 20.92 & 111.05 & 36.45 & 36.45 & 13.79 & 22.11 \\
Rubber + CB $(4.0 \times 2.0 \mathrm{~m})$ & 25.35 & 112.68 & 34.92 & 34.92 & 11.88 & 16.92 \\
Rubber + CB $(3.0 \times 3.0 \mathrm{~m})$ & 21.36 & 11.38 & 22.61 & 27.61 & 13.58 & 18.68 \\
Rubber + CB $(2.0 \times 2.0 \mathrm{~m})$ & 19.67 & 10.98 & 25.66 & 25.66 & 6.95 & 37.01 \\
LSD $(0.05)$ & 4.13 & 2.68 & 3.36 & 5.51 & 6.1 & 2.31 \\
\hline
\end{tabular}

Values in parenthesis are spacing of cooking banana within the main crop (rubber) avenues.

Table 2.

Earth worm cast, biomass (fresh weight) and abundance as affected by cooking banana inter crop at different spacing within rubber avenues at the third and sixth years after plantation establishment.

\begin{tabular}{|c|c|c|c|c|c|c|}
\hline \multirow{3}{*}{ Treatment } & \multicolumn{3}{|c|}{$3^{\text {rd }}$ Year Earth Worm } & \multicolumn{3}{|c|}{$6^{\text {th }}$ Year Earth Worm } \\
\hline & \multirow{2}{*}{$\begin{array}{c}\text { Cast } \\
\left(\mathrm{g} \cdot \mathrm{m}^{-2}\right)\end{array}$} & Biomass & Abundance & Cast & Biomass & Abundance \\
\hline & & \multicolumn{2}{|c|}{$\left(\mathrm{No} \cdot \mathrm{m}^{-2}\right)$} & $\left(\mathrm{g} \cdot \mathrm{m}^{-2}\right)$ & \multicolumn{2}{|c|}{$\left(\mathrm{No} \cdot \mathrm{m}^{-2}\right)$} \\
\hline Rubber sole $6.7 \times 3.4 \mathrm{~m}$ & 195.04 & 46.57 & 127.09 & 350.92 & 49.34 & 138.32 \\
\hline Rubber $+\mathrm{CB}(6.7 \times 3.4 \mathrm{~m})$ & 262.87 & 50.13 & 151.79 & 430.14 & 53.52 & 145.44 \\
\hline Rubber + CB $(4.0 \times 2.0 \mathrm{~m})$ & 269.17 & 54.64 & 136.05 & 442.06 & 64.08 & 155.55 \\
\hline Rubber + CB $(3.0 \times 3.0 \mathrm{~m})$ & 270.57 & 58.56 & 138.96 & 414.16 & 64.64 & 150.52 \\
\hline Rubber $+\mathrm{CB}(2.0 \times 2.0 \mathrm{~m})$ & 275.19 & 60.50 & 143.96 & 410.43 & 73.62 & 53.20 \\
\hline $\operatorname{LSD}(0.05)$ & 8.35 & 5.12 & 10.33 & 21.11 & 4.92 & 11.31 \\
\hline
\end{tabular}

Values in parenthesis are spacing of cooking banana within the main crop (rubber) avenues.

trees as shown by girth sizes or range across the treatments (Table 3); trees in the intercrops showed faster rate as measuerd in per centages over time with most of the sampled trees attaining $\geq 50 \mathrm{~cm}$ girth at end of the $5^{\text {th }}$ year compared to the sole. The attainment of tappability amongst the rubber trees in the intercrop increased as the spacing of $\mathrm{CB}$ within the avenues narrowed, with approximately $85 \%$ of the sampled trees in the plot with $\mathrm{CB}$ at $2 \times 2 \mathrm{~m}$ spacing attaining $>50 \mathrm{~cm}$ girth at the fifth year after planting. Across the treatments, plots where $\mathrm{CB}$ was spaced $2 \times 2 \mathrm{~m}$ and $3 \times 3 \mathrm{~m}$ within the tree avenue, the proportion of trees attaining the tappable girth size exceeded the standard $60 \%$ often recommended for economic tapping and this occured at the fifth year after planting.

\section{Dry Rubber Yield}

The mean annual yield of rubber (DRC) within the inter crops were significantly higher than those of the sole plot (Table 4). At the onset of tapping (1999), the highest yield of 1.3 $\mathrm{t} \cdot \mathrm{ha}^{-1}$ DRC was obtained from plots where CB was inter cropped at $4 \times 2 \mathrm{~m}$ spacing. This trend continued all through the data period. However, the yield from plots with CB being spaced at $3 \times 3 \mathrm{~m}$ and $2 \times 2 \mathrm{~m}$ were higher than those from plots where $\mathrm{CB}$ was intercropped at $6.7 \times 3.4 \mathrm{~m}$ spacing within the rubber avenues.

\section{Discussion}

\section{Soil Nutrient and Earthworm Activities}

The result of this study showed the potentials of rubber plantation in improving nutrient status of soil as well as organic matter build up as the years of establishment progress (Table 1); irrespective of the cropping system. This observation buttressed the widely reported potentials of rubber plantation is building 
Table 3.

Effects of cooking banana (CB) spacing in an intercrop with rubber on the maturity rate of rubber based on girth ranges between the $3^{\text {rd }}$ and $6^{\text {th }}$ year after plantation establishment.

\begin{tabular}{|c|c|c|c|c|c|}
\hline \multirow{2}{*}{ Treatment } & \multirow{2}{*}{ Girth Range (cm) } & \multirow{2}{*}{$\begin{array}{c}\text { Years } \\
\mathbf{3}\end{array}$} & \multicolumn{2}{|c|}{ After } & \multirow{2}{*}{$\begin{array}{c}\text { Planting } \\
6\end{array}$} \\
\hline & & & 4 & 5 & \\
\hline \multicolumn{6}{|c|}{$(\%)$} \\
\hline \multirow{6}{*}{ Rubber sole $6.7 \times 3.4 \mathrm{~m}$} & $<30$ & 67 & 53 & 0 & 0 \\
\hline & $31-35$ & 30 & 42 & 0 & 0 \\
\hline & $36-40$ & 3 & 5 & 25.5 & 6 \\
\hline & $41-45$ & 0 & 0 & 15.5 & 7 \\
\hline & $46-50$ & 0 & 0 & 28.5 & 22 \\
\hline & $>50$ & 0 & 0 & 30.5 & 65 \\
\hline \multirow{6}{*}{ Rubber $+\mathrm{CB}(6.7 \times 3.4 \mathrm{~m})$} & $<30$ & 58 & 33 & 0 & 0 \\
\hline & $31-35$ & 25 & 38 & 0 & 0 \\
\hline & $36-40$ & 17 & 29 & 10.5 & 3.5 \\
\hline & $41-45$ & 0 & 0 & 16 & 4.5 \\
\hline & $46-50$ & 0 & 0 & 25 & 7 \\
\hline & $>50$ & 0 & 0 & 48.5 & 85 \\
\hline \multirow{6}{*}{ Rubber $+\mathrm{CB}(4.0 \times 2.0 \mathrm{~m})$} & $<30$ & 50 & 28 & 0 & 0 \\
\hline & $31-35$ & 36 & 52 & 0 & 0 \\
\hline & $36-40$ & 14 & 20 & 0 & 0 \\
\hline & $41-45$ & 0 & 0 & 20.5 & 0 \\
\hline & $46-50$ & 0 & 0 & 30 & 10 \\
\hline & $>50$ & 0 & 0 & 49.5 & 90 \\
\hline \multirow{6}{*}{ Rubber $+\mathrm{CB}(3.0 \times 3.0 \mathrm{~m})$} & $<30$ & 45 & 20 & 0 & 0 \\
\hline & $31-35$ & 32 & 50 & 0 & 0 \\
\hline & $36-40$ & 23 & 23.5 & 0 & 0 \\
\hline & $41-45$ & 0 & 6.5 & 15 & 0 \\
\hline & $46-50$ & 0 & 0 & 23.5 & 8 \\
\hline & $>50$ & 0 & 0 & 61.5 & 92 \\
\hline \multirow{6}{*}{ Rubber $+\mathrm{CB}(2.0 \times 2.0 \mathrm{~m})$} & $<30$ & 42 & 13 & 0 & 0 \\
\hline & $31-35$ & 27 & 9.5 & 0 & 0 \\
\hline & $36-40$ & 16 & 30 & 0 & 0 \\
\hline & $41-45$ & 14 & 37 & 10.5 & 3 \\
\hline & $46-50$ & 1 & 10.5 & 5 & 3.5 \\
\hline & $>50$ & 0 & 0 & 84.5 & 93.5 \\
\hline
\end{tabular}

Value in parenthesis are spacing of cooking banana $(\mathrm{CB})$ within the main crop (rubber) avenues.

up soil nutrient and organic $\mathrm{C}$ through efficient nutrient cycling mechanism (Delabarre \& Serier, 2001) and enhanced environmental conservation facilitated by biodiversity maintenance and conservation similar to natural forest ecosystem (Beukema et al., 1997).

On annual basis, the mean (6 years) values of the soil organic $\mathrm{C}$ stock and stocks of $\mathrm{N}, \mathrm{P}, \mathrm{K}, \mathrm{Mg}$ and $\mathrm{Ca}$ observed across the treatments in this study are within the range reported by Delabarre and Serier (2001) as a mean annual value of 25 year rub- ber plantation, but above the organic $\mathrm{C}$ stock recorded (Nolte et al., 2001) from a natural fallow land of similar age in Cameroon, under a similar soil. The intercropping of cooking banana within the rubber avenue resulting to a significantly $(\mathrm{P}>0.05)$ higher organic $\mathrm{C}$ stock and stocks of $\mathrm{P}$ and exchangeable base cations except K, relative to the sole rubber (Table 1) could be due to higher biomass generation and retention from the banana residue.

Similar higher nutrient levels have been reported in banana 
Table 4.

Mean yield performance of rubber between 1990 and 2001 as influenced by cooking banana spacing within rubber avenues in an intercrop system.

\begin{tabular}{ccccc}
\hline \multirow{2}{*}{ Treatment } & \multicolumn{4}{c}{$\begin{array}{c}\text { Mean annual yield rubber } \\
\left(\mathbf{k g ~ D R C} \mathbf{~ h a ~}^{-1} \cdot \mathbf{y r}^{-1} \text { ) }\right.\end{array}$} \\
\cline { 2 - 5 } & $\mathbf{1 9 9 9}$ & $\mathbf{2 0 0 0}$ & $\mathbf{2 0 0 1}$ & Mean \\
\hline Rubber sole $6.7 \times 3.4 \mathrm{~m}$ & 920.7 & 1636.9 & 1736.6 & 1431.4 \\
Rubber + CB $(6.7 \times 3.4 \mathrm{~m})$ & 1024 & 1644.6 & 1745.8 & 1471.5 \\
Rubber + CB $(4.0 \times 2.0 \mathrm{~m})$ & 1264.8 & 1835.8 & 1937.6 & 1679.4 \\
Rubber + CB $(3.0 \times 3.0 \mathrm{~m})$ & 1049.8 & 1782.3 & 1884.6 & 1572.2 \\
Rubber + CB $(2.0 \times 2.0 \mathrm{~m})$ & 1015.4 & 1705.8 & 1810.8 & 1510.7 \\
LSD $(0.05)$ & 20.8 & 60.3 & 43.6 & \\
\hline
\end{tabular}

Values in parenthesis are the spacings of cooking banana (CB) within the immature rubber avenues.

associated cropping system (Bekundal et al., 2000) compared to other cropping systems. This is attributed among other things to the reduced rate of nutrient loss ( leaching) resulting from early shading of the surface soil by the banana plant, applied mulching materials and retention of a large quantity of the plant residue after harvest. However, a lower level of K Stock was recorded from the intercropped plots compared to the sole. This could be ascribed to higher uptake of $\mathrm{K}$ and buttressed by the observed decline in the nutrient as the spacings of the intercrop component narrowed. Similar observation was made (Wilson, 1985) who reported the storage of a greater proportion of $\mathrm{K}$ at the fruit portion of the plant compared to the other parts. The implication is that as the fruit are being harvested and taken away from the farm for consumption, a large amount of $\mathrm{K}$ is being exported from the field and could have some adverse effect on the development of the rubber.

At the end of the first three years of the intercrops, the observed significantly higher earthworm activities (surface cast, biomass and abundance) in plots with cooking banana at closer spacing (Table 2) could be as a result of shade provided by the banana plant. Since the banana plant were at closer spacing $(2 \times$ $2 \mathrm{~m}$ ) within the rubber avenue, their leaves could have been closely interlocked than those at the wider spacing $(6.7 \times 3.4 \mathrm{~m}$ or $4 \times 2 \mathrm{~m}$ ); thus providing better shade and moisture conservation - a mechanism known to affect earthworm activities. The higher earthworm activities observed in the plots with cooking banana at $4 \times 2 \mathrm{~m}$ at the sixth year sampling (maturity of plantation) could be ascribed to higher organic matter content in that plot (Table 1) resulting from the presence of banana plants and its residue. Thus the observed higher earthworm activities in the intercrop compared to the sole rubber is in order and its implications on nutrient cycling and other ecosystem services are paramount.

\section{Rubber Tree Maturity Period}

As shown in Table 3, inter-cropping shortened the maturity (tappability) period of the rubber tree with higher percentages of trees attaining maturity in plots with cooking banana at closer spacings $2 \times 2 \mathrm{~m}$ and $3 \times 3 \mathrm{~m}$ compared to others, at five years after planting. Theis observation could partly be attributed to improved management methods resulting from integration of banana (Esekhade et al., 2005) and the early shading effect of the banana which may have alleviated the commonly observed radiation induced photosynthic reduction in young Hevea plants due to easy penetration of sun rays during the early growth stage under sole rubber cropping system (Senevirathna et al., 2003). Such shading effect is known to promote leave production, with an associated leave area increase per plant. Similarly, increased growth rate and dry matter accumulation have been observed among rubber plants intercropped with cassava (Esekhade, 2004).

The observed non-impairment of rubber tree growth and maturity by cooking banana, even at closer spacings is in line with the work of Rodrigo et al. (1997). Also the higher values of soil nutrient stocks and biological activities in the intercrop plots (Tables 1 and 2) may have had some positive effect on the growth of the tree and consequently its maturity. Hauser et al. (1997) observed a positive relation between earth worm activeties and crop performance (growth and yield).

\section{Dry Rubber Yield}

The positive effect of the intercrops on rubber did not only enhance the maturity (tappability) period of rubber, but also affected the latex yield measured as dry rubber content (DRC), compared to the sole. However, the pattern of DRC values across the treatments did not follow the trend observed for the maturity rate (\%) of the plants, rather the highest DRC values were consistently obtained from plots where the trees were intercropped with cooking banana at $4 \times 2 \mathrm{~m}$ (Table 4). This could be due to high soil nutrient concentration under the treatment (Table 2) aswell as soil biological activities (earth worm) which may have influence yield. The effect of soil nutrient status on dry rubber content is reported by Delabarre and serier (2002) and Esekhade et al. (2005).

\section{Conclusion}

The problem of overcoming the zero income phrase associated with rubber cultivation has necessitated the research into the environmental and economic implication of intercropping of rubber with other early maturing high value crops. This study revealed that not only did intercropping of rubber with cooking banana resulted to improve soil fertility in terms of soil nutrient and biological activities (earth worm) but it also shortened the maturity period of the tree compared to the sole. However, intercropping banana at closer spacings within the avenue needs further investigation because of the reduction in soil $\mathrm{K}$ stock. From the information gathered from the study, intercropping with cooking banana at $4 \times 2 \mathrm{~m}$ within the rubber avenue ensures better rubber performance in terms of yield and soil resources conservation.

\section{REFERENCES}

Anderson, J. M., \& Ingram, J. S. I. (Eds.) (1993). Tropical soil biology and fertility: A handbook of methods (2nd ed.). Wallingford: CAB International.

Bekunda, M. A., Wortinann, C. S., Bwamiki, D. P., \& Okwakol, M. (2000). Potentials and challenges of soils fertility management in Banana based cropping systems of Eastern Africa. In M. P. Gichuru, A. Bationo, M. A. Bekundia, et al. (Eds.), Soil fertility management in Africa: A regional perspective (pp. 123-146). Nairobi: Academy Science Publishers.

Beukema, H., Stolle, F., Van Noordwijk, M., \& De Foresta, H. (1997). 


\section{T. U. ESEKHADE ET AL.}

Biodiversity in rubber agroforestry. Smallholder Rubber Agroforestry Project, ICRAF South East Asian Regional Research Programme, Bogor.

Delabarre, M. A., \& Serier J. B. (2001) Rubber. Tropical agriculturalist series. Wageningen: CTA and Macmillan.

Ellert, B. H., \& Bettary, J. R. (1995). Calculation of organic matter and nutrient stored in soils under contrasting management regimes. $\mathrm{Ca}$ nadian Journal of Soil Science, 75, 529-538. doi:10.4141/cjss95-075

Esekhade, T. U., \& Ojiekpon, I. F. (1997). Effects and economic viability of intercropping cooking banana with rubber in Nigeria. Indian Journal of Natural Rubber Research, 10, 91-96.

Esekhade, T. U. (2003). Effect of phosphorus and selected rubber based cropping systems on the early development of rubber (Hevea brasiliensis (Wild e.x.A.de Juss) mueller argoviensis) on acid soil. Ph.D. Thesis, Ibadan: University of Ibadan.

Esekhade, T. U., Okore, I. K., Ogeh, J., \& Idoko, S. O. (2005). Effect of fertilizer and mulch on the growth and yield of intercropped rubber/cooking banana and soil properties. Journal of Sustainable Agriculture and the Environment, 7, 10-20.

Fagbami, A., \& Fapohunda A. (1986). Slur imagery for soil mapping and regional planning in western Nigeria. In M. J. Eden (Ed.), Remote sensing and tropical land management and parry. New York: John Wiley\& Sons Ltd.

Hauser, S., Vanlauwe, B. Asawalam, D. O., \& Norgrove, L. (1997) Role of earthworm in traditional and improved low-input agricultural systems in West Africa. In L. Brussard, et al. (Eds.), Soil ecology in sustainable agricultural systems (pp. 113-136). New York: Lewis Publications.

IRSG (2000). Rubber statistical bulletin. Wembley: International Rubber Study Group.

Lydia, P. O., Teresita, I. C., \& Nelson, T. B. (1999). Natural rubber: A farming option for Agrarian return communities in Mindango, Philippines. Proceeding of IRRDB Symposium. Hainan: Hainan Publishing House.

Nolte, C., Koho-Same, J., Moukam, A., Thenkabai, P. S. Weise, S. F., Woomer, P. L. \& Zapfack L. (2001). Land-use characterization and estimate of carbon stock in the alternative to slash-and-burn bench mark areas in Cameroon. IITA Resources and Crop Management Research Monograph No. 28, 9-21.

Noordwijr, M. V. (2002). Nutrient cycling in ecosystem and nutrient flows in agro ecosystem. Newsletter on Soil Fertility and Fallow Management in the Up/and Tropics No. 2.

Page, A. L., Miller, R. H., \& Keeney, D. R. (1982). Methods of soil analysis part 2: Chemical and microbial properties. Madison: American Society of Agronomy, Inc.

Rao, P. S., Saraswathyamma, C. K., \& Sethuraji, M. R. (1998). Studies on the relationship between yield and meteorological parameters of Para rubber tree (Hevea brasiliensis). Agricultural and Forest Meteorology, 90, 235-245.

Rodrigo, V. H. L., Stirling, C. M., Teklehaimanot, Z., \& Nugwale, A. (1997). Effect of planting density on growth and development of component crops in rubber/banana intercropping system. Field Crop Research, 52, 95-108 doi:10.1016/S0378-4290(96)01069-6

Rodrigo, V. H. L. Stirling, C. M., Teklehaimanot, Z., \& Nugwale, A. (2001). Intercropping with banana to improve fractional interception and radiation-use efficiency of immature rubber plantation. Field Crop Research, 69, 237-249. doi:10.1016/S0378-4290(00)00147-7

Senevirathan, A. M. W. K., Stirling. C. M., \& Rodrigo, V. H. L. (2003). Growth, Photosynthetic performance and shade adaptation of rubber (Hevea brasiliensis) growth in natural shade. Tree Physiology, 23, 701-712.

Vonuekull, H. R., \& Mutert, E. (1995). Global extent, development and economic impact of acid soils. Plant and Soil, 171, 1-15. doi:10.1007/BF00009558

Wilson, K. C. (1985). Mineral and fertilizer needs. In M. N. Clifford, \& K. C.Wilson (Eds.), Coffee: Botany, biochemistry and production of beans and Beverage. London: Croom Helm Ltd.

Woomer, D. L. Bekunda, M. A., \& Nkalubo, S. T. (1998) Site characterization for organic resource transfer studies: The century model approach. African Crop Science Journal, 6, 205-214.

Zainol, A. E, Mannual, W., \& Suden, M. N ( 1993). Effect of intercropping systems on surface processes in acid ultisols: Changes in soil chemical properties and their influence on crop performance. Journal of Natural Rubber Research, 8, 124-136. 